
v.11, n.3, 30 quadrimestre de 2016. Disponível em: www.univali.br/direitoepolitica - ISSN 19807791.

\title{
A TRIBUTAÇÃO DAS OPERAÇÕES COM CRÉDITO DE CARBONO
}

\author{
THE TAXATION OF CARBON CREDIT OPERATIONS
}

\author{
Jéssica Cindy Kempfer ${ }^{1}$
}

SUMÁRIO: Introdução; 1 . O protocolo de Kyoto e o mecanismo de desenvolvimento limpo (MDL); 1.1. A convenção-quadro das nações unidas sobre mudança do clima e o protocolo de Kyoto; 1.2. Os MDL (mecanismos de desenvolvimento limpo); 1.3. As RCES (reduções certificadas de emissão); 2. O mercado de créditos de carbono; 2.1. Créditos de carbono e o mercado de créditos de carbono; 2.2. A natureza jurídica dos créditos de carbono; 3. Aspectos tributários dos créditos de carbono; 3.1. Tributação sobre a circulação das reduções certificadas de emissões. 3.2. Tributação sobre as receitas auferidas com reduções certificadas de emissões; 3.2.1. Contribuição ao programa de integração social e de formação do patrimônio do poder público; 3.2.2. Contribuição para o financiamento da seguridade social (COFINS); 3.3 . Tributação sobre o lucro e rendimentos auferidos com reduções certificadas de emissões; 3.3.1. Imposto sobre a renda e proventos de qualquer natureza (IR); 3.3.2. Contribuição social sobre o lucro líquido (CSLL); Considerações Finais; Referências das Fontes Citadas.

\section{RESUMO}

A degradação do ambiente e o aquecimento global desenfreado, causados principalmente pela emissão de gases poluentes, vêm proporcionando discussões a respeito de medidas de combate ao aumento de emissão de gases de efeito estufa. A ratificação do Protocolo de Kyoto, por 141 países, fixou metas de redução de emissões de Gases de Efeito Estufa e estabeleceu a criação do chamado Mecanismo de Desenvolvimento Limpo (MDL), que serão projetos emissores de Reduções Certificadas de Emissões (RCEs), as quais podem ser transacionadas. $O$ presente artigo trata da incidência tributária nos negócios jurídicos que envolvem as RCEs, abordando a natureza jurídica de tais certificados e apontando a tributação aplicável.

Palavras-Chave: Direito tributário. Protocolo de Kyoto. Créditos de Carbono. Reduções Certificadas de Emissões. Mecanismos de Desenvolvimento Limpo.

\footnotetext{
${ }^{1}$ Especialista em Direito Tributário Empresarial e Mestranda em Direito pela IMED - Faculdade Meridional, Passo Fundo, Rio Grande do Sul, Brasil, linha de pesquisa "Fundamentos do Direito e da. Democracia". E-mail: jessicakempfer@gmail.com
} 
KEMPFER, Jéssica Cindy. A tributação das operações de crédito de carbono. Revista Eletrônica Direito e Política, Programa de Pós-Graduação Stricto Sensu em Ciência Jurídica da UNIVALI, Itajaí, v.11, n.3, $3^{\circ}$ quadrimestre de 2016. Disponível em: www.univali.br/direitoepolitica - ISSN 19807791.

\section{ABSTRACT}

The environmental degradation and the uncontrolled global warming, mainly caused by the emission of pollutant gases, have been providing discussions about how to combat the increase of greenhouse gas emissions. The ratification of the Kyoto Protocol by 141 countries, has set greenhouse gas emission reduction targets and established the creation of the called Clean Development Mechanism (CDM). These will be issuers projects of Certified Emission Reductions (CERs), which can be traded. This article deals with the tax incidence in legal transactions involving CERs, addressing the legal status of such certificates and pointing the applicable taxes.

Keywords: Tax Low. Kyoto Protocol. Carbon Credits. Certified Emissions. Reductions. Clean Development Mechanisms.

\section{INTRODUÇÃO}

O combate ao aquecimento global gerou reflexos no sistema jurídico internacional. Ele é responsável pelas mudanças climáticas que comprometem o meio ambiente e a saúde da população, gerando grande impacto sobre as atividades econômicas de todos os países do globo.

O efeito estufa pode ser apontado como principal causador do aquecimento global. Contudo, o aumento da temperatura do planeta não se dá apenas devido a esse fenômeno e sim ao excesso dele, causado pelas práticas poluentes do homem, o que potencializa o efeito estufa e acaba gerando os impactos negativos sobre o meio ambiente.

Assinado pelo Brasil em 1993, o Protocolo de Kyoto compromete os países signatários à reduzir suas emissões de gases poluentes, com um panorama de cotas mundiais de redução. Prevê ainda, a redução certificada dos gases responsáveis pelo efeito estufa, dessa redução nascem as RCE (Reduções Certificadas de Emissões), geradoras de Créditos de Carbono.

Assim, foram criadas novas possibilidades de investimento, oriundas da comercialização das RCEs. Este novo mercado, o chamado "Mercado de Carbono" permite aos países signatários do Protocolo de Kyoto, que não alcançaram suas 
KEMPFER, Jéssica Cindy. A tributação das operações de crédito de carbono. Revista Eletrônica Direito e Política, Programa de Pós-Graduação Stricto Sensu em Ciência Jurídica da UNIVALI, Itajaí, v.11, n.3, $3^{\circ}$ quadrimestre de 2016. Disponível em: www.univali.br/direitoepolitica - ISSN 19807791.

metas de redução, a aquisição das Reduções Certificadas de Carbono excedentes das cotas dos países que produzem menos dióxido de carbono.

As operações de compra e venda dos chamados "créditos de carbono" são realizadas em bolsa de valores, através de leilões eletrônicos previamente anunciados em editais que tornem pública sua realização, nos quais podem participar instituições públicas ou privadas.

Longe de esgotar a matéria, a proposta do presente artigo é analisar a tributação na comercialização das Reduções Certificadas de Emissão, ou seja, analisá-la sob o prisma de negócio realizado entre pessoas jurídicas, mas não entre federações, considerando que inexiste opinião unânime acerca do tratamento contábil e tributário das referidas operações.

O presente trabalho, quando à metodologia empregada, é baseado pelo método indutivo tanto na fase de investigação quando na fase de tratamento de dados.

\section{O PROTOCOLO DE KYOTO E O MECANISMO DE DESENVOLVIMENTO LIMPO (MDL)}

Ao refletir sobre o meio ambiente e desenvolvimento sustentável, podemos perceber que, atualmente, são conceitos discutidos amplamente, devido à crescente preocupação da sociedade ocidental no que se refere à preservação do ambiente. Em face disso, ano após ano, a sociedade mundial tem elaborado diversos documentos com a finalidade de proteção efetiva do meio ambiente, os quais serão estudados no decorrer deste capítulo.

\subsection{A CONVENÇÃO-QUADRO DAS NAÇÕES UNIDAS SOBRE MUDANÇA DO CLIMA E O PROTOCOLO DE KYOTO}

O combate ao aquecimento global gerou reflexos no sistema jurídico internacional. O efeito estufa pode ser apontado como principal causador do aquecimento global. Contudo, o aumento da temperatura do planeta não se dá 
KEMPFER, Jéssica Cindy. A tributação das operações de crédito de carbono. Revista Eletrônica Direito e Política, Programa de Pós-Graduação Stricto Sensu em Ciência Jurídica da UNIVALI, Itajaí, v.11, n.3, $3^{\circ}$ quadrimestre de 2016. Disponível em: www.univali.br/direitoepolitica - ISSN 19807791.

apenas devido a esse fenômeno e sim ao excesso dele, causado pelas práticas poluentes do homem.

Assim, a preocupação com as mudanças climáticas ocasionou, por parte dos países desenvolvidos, uma série de acordos multilaterais que visam a redução dos gases do efeito estufa, através de projetos de MDL (mecanismos de desenvolvimento limpo).

Com o objetivo principal de estabilizar as concentrações dos gases de efeito estufa na atmosfera, foi firmada a Convenção-Quadro das Nações Unidas sobre mudanças climáticas (UNFCCC) ${ }^{2}$ que teve seu texto adotado na Sede das Nações Unidas, em Nova Iorque, no dia 09.05.1992 a qual esteve aberta para assinaturas no Rio de Janeiro de Janeiro de 04 a 14 de junho de $1992^{3}$. O Brasil aderiu a Convenção-Quadro em 1992, sendo ratificada em 1994 e promulgada pelo Decreto 2.652 em 01 de julho de 1998.

Tal convenção pode ser dividida em quatro tipos de normas: a) os dispositivos introdutórios; b) as obrigações relativas às fontes de emissões e à redução da concentração de gases que contribuem para o aquecimento global por meio de sumidouros; c) as relativas à cooperação e à troca de informações e dispositivos acerca de alterações da Convenção; e d) os anexos e os protocolos ${ }^{4}$.

O documento contém, preponderantemente, meios cooperativos para a conquista de suas metas, não definindo, portanto, a forma de atingir seu objetivo principal, apenas estabelecendo os mecanismos que darão continuidade ao processo de negociação em torno dos instrumentos necessários para que ele seja alcançado ${ }^{5}$.

${ }^{2}$ Do ingles United Nations Framework Convention on Climate Change.

${ }^{3}$ LIMIRO, Danielle. Créditos de Carbono: Protocolo de Kyoto e Projetos de MDL. Curitiba: Juruá, 2012. p. 35.

${ }^{4}$ ACCIOLY; CASELLA; SILVA. Manual de Direito Internacional Público. p. 715.

5 LIMIRO, LIMIRO, Danielle. Créditos de Carbono: Protocolo de Kyoto e Projetos de MDL. Curitiba: Juruá, 2012. p. 36. 
KEMPFER, Jéssica Cindy. A tributação das operações de crédito de carbono. Revista Eletrônica Direito e Política, Programa de Pós-Graduação Stricto Sensu em Ciência Jurídica da UNIVALI, Itajaí, v.11, n.3, $3^{\circ}$ quadrimestre de 2016. Disponível em: www.univali.br/direitoepolitica - ISSN 19807791.

Para a tomada de decisões necessárias, visando à implementação da ConvençãoQuadro, foi instituída a Conferência das Partes (COP), onde na sua terceira sessão ordinária anual (COP3), realizada no período de 01/12 a 10/12 de 1997, na cidade de Kyoto no Japão, contando com representantes de 159 nações, culminou no Protocolo de Kyoto, um dos marcos mais importantes desde a criação da Convenção-Quadró ${ }^{\text {. }}$

O Protocolo de Kyoto é um acordo multilateral que visa à criação de mecanismos de flexibilização para garantir o cumprimento dos compromissos de emissões previsto na Convenção-Quadro sobre Mudanças Climáticas da ONU. O documento foi considerado uma inovação por conter disposições que obrigavam também os países mais desenvolvidos a reduzir suas emissões de gases poluentes, impondo penalidades para o seu não cumprimento.

O protocolo indica que é possível definir compromissos de redução para os países desenvolvidos com base no aumento de temperatura induzido. Assim, os países que atualmente e historicamente possuem um aumento de temperatura maior, teriam o maior peso em termos de compromissos e redução.

\subsection{OS MDL (MECANISMOS DE DESENVOLVIMENTO LIMPO)}

O mecanismo de desenvolvimento limpo é o instrumento "jurídico-econômico" capaz de reduzir a emissão de gases do efeito estufa (GEE) na atmosfera. A redução, por sua vez, gera créditos de carbono, que serão utilizados por agentes econômicos dos países que integram a Convenção-Quadro sobre Mudanças Climáticas, para compensação do cumprimento de suas obrigações de redução de GEE, fixadas no Protocolo de Kyoto.

\footnotetext{
6 LIMIRO, LIMIRO, Danielle. Créditos de Carbono: Protocolo de Kyoto e Projetos de MDL. Curitiba: Juruá, 2012. p. 37.
} 
KEMPFER, Jéssica Cindy. A tributação das operações de crédito de carbono. Revista Eletrônica Direito e Política, Programa de Pós-Graduação Stricto Sensu em Ciência Jurídica da UNIVALI, Itajaí, v.11, n.3, $3^{\circ}$ quadrimestre de 2016. Disponível em: www.univali.br/direitoepolitica - ISSN 19807791.

A origem do MDL está na mobilização da comunidade internacional, que, por meio da Organização das Nações Unidas (ONU), busca soluções para a questão socioambiental causada pelo fenômeno mundial de mudanças climáticas ${ }^{7}$.

A criação do MDL e dos demais instrumentos de combate aos gases do efeito estufa foi desencadeada pela divulgação, em 1990, pelo IPCC (Intergovernmental Panelon Climate Change ${ }^{8}$ ), da confirmação das evidências científicas da mudança mundial do clima. Isso fez com que a ONU estabelecesse a Convenção Quadro de Mudanças Climáticas (CQMC), aberta para assinatura dos países participantes da "Cúpula da Terra" em janeiro de 1992 e passando a vigorar em 1994, contabilizando a assinatura de mais de 185 países.

A CQMC, que tem por objetivo alcançar a necessária redução das emissões de GEE, deveria ser seguida de protocolos adicionais que detalhariam as medidas adicionais a serem tomadas pelos diversos países para o fim de alcançar o objetivo almejado. Dessa forma, para complementar a Convenção, foi realizada a $3^{a}$ Conferência Anual das Partes da CQMC (COP-3) ${ }^{9}$, onde se pactuou o Protocolo de Kyoto, instrumento criador do MDL.

Assim, o mecanismo de desenvolvimento limpo foi institucionalizado pelo art. 12 do Protocolo de Kyoto:

O objetivo do mecanismo de desenvolvimento limpo deve ser assistir às Partes não incluídas no Anexo I para que atinjam o desenvolvimento sustentável e contribuam para o objetivo final da Convenção, e assistir às Partes incluídas no Anexo I para que cumpram seus compromissos quantificados de limitação e redução de emissões, assumidos no Artigo $3^{10}$.

\footnotetext{
7 LORENZONI NETO, Antonio. Contrato de Créditos de Carbono. Curitiba: Juruá, 2012. p. 21.

${ }^{8}$ Painel Intergovernamental sobre mudanças climáticas.

${ }^{9}$ FRANGETTO, Flavia Witkowski; GAZINI, Flávio Rufino. Viabilização Jurídica do Mecanismo de Desenvolvimento Limpo (MDL) no Brasil - O Protocolo de Quioto e a Cooperação Internacional. São Paulo: IIEB - Instituto Internacional de Educação do Brasil, 2002. p. 30.

${ }^{10}$ Protocolo de Kyoto, 1997. Art. 12, §2.
} 
KEMPFER, Jéssica Cindy. A tributação das operações de crédito de carbono. Revista Eletrônica Direito e Política, Programa de Pós-Graduação Stricto Sensu em Ciência Jurídica da UNIVALI, Itajaí, v.11, n.3, $3^{\circ}$ quadrimestre de 2016. Disponível em: www.univali.br/direitoepolitica - ISSN 19807791.

Podem ser consideradas atividades de projeto de MDL aquelas implementadas nos países em desenvolvimento, que visam à redução das emissões de gases de efeito estufa (ou remoção), bem como colaborem para seu desenvolvimento, seja mediante investimentos em tecnologias mais eficientes ou mediante racionalização do uso da energia, florestamento e reflorestamento ${ }^{11}$.

Tendo em vista que as partes não integrantes do Anexo I da Convenção-Quadro estão isentas de redução de gases de efeito estufa durante o primeiro período estabelecido pelo Protocolo (2008 a 2012), cada tonelada de CO2 (dióxido de carbono) que as atividades referentes aos projetos de MDL deixarem de emitir na atmosfera dará origem às Reduções Certificadas de Emissão (RCE), que poderão ser negociadas e adquiridas pelas Partes Anexo I, com a finalidade de contribuírem para o cumprimento de suas metas internas de redução, constantes no Anexo B do Protocolo ${ }^{12}$.

Para serem consideradas atividades de projetos de $M D L$, a redução das emissões devem contemplar os gases de efeito estufa listados no Anexo A do Protocolo, quais sejam $\mathrm{CO} 2$ (dióxido de carbono), CH4 (gás metano), N2O (óxido nitroso), HFCs (hidrofluorcarbonos), PFCs (perfluorcarbonos), SF6 (hexafluoreto de enxofre).

Ainda, o projeto de MDL para ser válido, deverá realizar o desenvolvimento sustentável do país que o está recebendo ${ }^{13}$. Em outras palavras, que os países obtenham crescimento e lucro de forma adequada ecologicamente, que deverá ser discriminado no projeto.

Entretanto, o MDL recebeu definição aberta pelo Protocolo de Kyoto. Não houve disciplina específica quanto à execução do mecanismo, não obstante seja seu objetivo o de promover o desenvolvimento sustentável. Dessa forma, um agente econômico sediado em um país não integrante do Anexo I, pode promover a

\footnotetext{
${ }^{11}$ LIMIRO. Créditos de Carbono: Protocolo de Kyoto e Projetos de MDL. p. 64.

12 LORENZONI NETO. Contrato de Créditos de Carbono. p. 64.

13 Protocolo de Kyoto, 1997. Art. 12. §1 e 2.
} 
KEMPFER, Jéssica Cindy. A tributação das operações de crédito de carbono. Revista Eletrônica Direito e Política, Programa de Pós-Graduação Stricto Sensu em Ciência Jurídica da UNIVALI, Itajaí, v.11, n.3, $3^{\circ}$ quadrimestre de 2016. Disponível em: www.univali.br/direitoepolitica - ISSN 19807791.

implementação de um projeto de $\mathrm{MDL}$, gerar créditos de carbono que serão de sua propriedade e comercializá-los conforme sua conveniência ${ }^{14}$.

\subsection{AS RCES (REDUÇÕES CERTIFICADAS DE EMISSÃO)}

As Reduções Certificadas de Emissões (Créditos de Carbono), são certificados emitidos para uma pessoa física ou jurídica que reduziu sua emissão de gases do efeito estufa. Elas são quantificadas conforme Decisão 17/CP.7, formulada na conferência das partes da Convenção-Quadro das Nações Unidas, em 2001:

Uma 'redução certificada de emissão' ou 'RCE' é uma unidade emitida em conformidade com o Artigo 12 e os seus requisitos, bem como as disposições pertinentes destas modalidades e procedimentos, e é igual a uma tonelada métrica equivalente de dióxido de carbono, calculada com o uso dos potenciais de aquecimento global, definidos na decisão 2/CP.3 ou conforme revisados subseqüentemente de acordo com o Artigo 5; ${ }^{15}$

Considerando os diferentes impactos no clima que os seus tipos de gases de efeito estufa ${ }^{16}$, listados no anexo A do Protocolo, causam, foi proposto um parâmetro, denominado Potencial de Aquecimento Global ${ }^{17}$ para compará-los.

O Potencial de Aquecimento Global visa uniformizar os resultados referentes ao potencial de aumento da temperatura global desses gases ao CO2 (dióxido de carbono), comparando os gases entre si e seus diferentes impactos sobre o clima $^{18}$. Nesse sentido, dispõe o Protocolo de Kyoto em seu art. 50, $\varsigma^{\circ}$ :

\footnotetext{
${ }^{14}$ LORENZONI NETO, Contrato de Créditos de Carbono. p. 28.

${ }^{15}$ Em inglêsCertified Emission Reduction - CER

16 O dióxido de carbono ou gás carbônico (CO2), o óxido nitroso (N2O), o metano (CH4), os hidrofluorocarbonetos (HFC), os perfluorocarbonetos (PFC) e o hexafluoreto de enxofre (SF6)

${ }^{17}$ Em inglês Global Warming Potencial - GWP

${ }^{18}$ LIMIRO. Créditos de Carbono: Protocolo de Kyoto e Projetos de MDL. p. 65
} 
KEMPFER, Jéssica Cindy. A tributação das operações de crédito de carbono. Revista Eletrônica Direito e Política, Programa de Pós-Graduação Stricto Sensu em Ciência Jurídica da UNIVALI, Itajaí, v.11, n.3, $3^{\circ}$ quadrimestre de 2016. Disponível em: www.univali.br/direitoepolitica - ISSN 19807791.

Os potenciais de aquecimento global utilizados para calcular a equivalência em dióxido de carbono das emissões antrópicas por fontes e das remoções antrópicas por sumidouros dos gases de efeito estufa listados no Anexo A devem ser os aceitos pelo Painel Intergovernamental sobre Mudança do Clima e acordados pela Conferência das Partes em sua terceira sessão. Com base no trabalho, inter alia, do Painel Intergovernamental sobre Mudança do Clima e no assessoramento prestado pelo Órgão Subsidiário de Assessoramento Científico e Tecnológico, a Conferência das Partes na qualidade de reunião das Partes deste Protocolo deve rever periodicamente e, conforme o caso, revisar o potencial de aquecimento global de cada um dos gases de efeito estufa, levando plenamente em conta qualquer decisão pertinente da Conferência das Partes. Qualquer revisão de um potencial de aquecimento global deve ser aplicada somente aos compromissos assumidos sob o Artigo $3 \mathrm{com}$ relação a qualquer período de compromisso adotado posteriormente a essa revisão.

Para a geração das RCEs, é necessário que a parte anfitriã demonstre, no decorrer do projeto de $\mathrm{MDL}$, o potencial de redução da quantidade de emissão original de gases poluentes. Deve a parte especificar, inicialmente, a quantidade de gases do efeito estufa emitidos antes do uso de tecnologia limpa e após a alteração do processo antes utilizado, realizar a verificação da diminuição de emissão dos gases poluentes. Essa verificação ocorre periodicamente durante a execução dos projetos de mecanismo de desenvolvimento limpo.

Após as medições de redução dos gases do efeito estufa, o projeto é verificado e apresentado à ONU, que certificará a parte. Posteriormente, serão emitidas, então, pelo Conselho Executivo do Protocolo, as Reduções Certificadas de Emissão (RCE), momento a partir do qual podem ser comercializadas pelas partes.

A compra e venda de RCE não faz exigência à solenidade formal. Para a sua concretização bastará que o empresário hospedeiro do projeto de MDL se obrigue a transferir o domínio das RCEs e que o empresário adquirente se obrigue a pagar o preço certo e determinado em dinheiro ${ }^{19}$.

19 LIMIRO. Créditos de Carbono: Protocolo de Kyoto e Projetos de MDL. p. 109-110. 
KEMPFER, Jéssica Cindy. A tributação das operações de crédito de carbono. Revista Eletrônica Direito e Política, Programa de Pós-Graduação Stricto Sensu em Ciência Jurídica da UNIVALI, Itajaí, v.11, n.3, $3^{\circ}$ quadrimestre de 2016. Disponível em: www.univali.br/direitoepolitica - ISSN 19807791.

O carbono tornou-se moeda de troca, a partir do momento em que países assinantes do acordo podem comprar e vender créditos de carbono. Adquiridos através de negociações internacionais, os chamados créditos de carbono são comercializados entre países mais poluidores e países com emissão reduzida de $\mathrm{CO}^{2}$, ou, ainda, entre empresas privadas.

Essa situação global indica a necessidade de se estabelecer novas estratégias democráticas de governança da regulamentação climática para a adequada gestão dos recursos naturais e o compartilhamento das responsabilidades ${ }^{20}$.

Não há dúvidas que as lesões ao meio ambiente afetam a toda coletividade global, não respeitando os limites territoriais dos Estados. Assim, considerando a forma como os sistemas vivos se relacionam e se desenvolvem, não é possível pensar em uma proteção ambiental efetiva em um território ou país de forma isolada.

A preocupação com o clima é, sem dúvidas, uma pauta transnacional. Um exemplo disso é o fato de que essa preocupação levou a ONU, organização com mais de 193 estados-membros, a realizar diversas convenções e acordos internacionais enfatizando a mudança do clima.

É fundamental, portanto, uma nova visão sobre as relações entre as nações uma vez que a demanda climática requer um tipo de governança internacional baseada na solidariedade e na cooperação necessário para assegurar a manutenção da vida na terra.

Nas palavras de Paulo Márcio Cruz e Zenildo Bodnar:

Não se pode imaginar medidas efetivas para a proteção e recuperação do ambiente, o que é fundamental para qualquer iniciativa com relação ao clima, sem essa nova maneira de enxergar as relações entre os Estados nacionais, baseada na cooperação e na solidariedade em espaços de

20 CRUZ, Paulo Márcio; BODNAR, Zenildo. O clima como necessidade de governança transnacional: reflexões pós-Copenhague 2009. Seqüência: Estudos Jurídicos e Políticos, Florianópolis, p. 319-339, nov. 2010. ISSN 2177-7055. Disponível em: <https://periodicos.ufsc.br/index.php/sequencia/article/view/2177-

7055.2010v31n60p319/15391>. Acesso em: 11 set. 2016. 
KEMPFER, Jéssica Cindy. A tributação das operações de crédito de carbono. Revista Eletrônica Direito e Política, Programa de Pós-Graduação Stricto Sensu em Ciência Jurídica da UNIVALI, Itajaí, v.11, n.3, $3^{\circ}$ quadrimestre de 2016. Disponível em: www.univali.br/direitoepolitica - ISSN 19807791.

governança para temas específicos, como é o caso do ambiente e do clima ${ }^{21}$.

A tutela ambiental tradicional, com foco nos estados, vem apresentando uma baixa eficácia em virtude da inércia destes na implementação de normas jurídicas. Já uma tutela ambiental com foco no mercado se mostra mais eficaz, uma vez que presente o interesse econômico na transação. Estes novos mercados vão além das tradicionais formas de estado e representam um processo de decisões transnacionais mais ágil.

Por isso importante se faz a análise desse novo mercado global que está se formando, bem como da tributação incidente nestas operações.

\section{O MERCADO DE CRÉDITOS DE CARBONO}

A redução de emissões ou o aumento na remoção dos gases do efeito estufa da atmosfera, advinda do projeto de Mecanismo de Desenvolvimento Limpo, gera a denominada Redução Certificada de Carbono (RCE) ou Crédito de Carbono.

Tal título, negociável em virtude de sua natureza comercial, será objeto de análise neste capítulo.

\subsection{CRÉdITOS DE CARBONO E O MERCADO DE CRÉDITOS DE CARBONO}

O mecanismo de desenvolvimento limpo é um método de flexibilização criado a partir do Protocolo de Kyoto que permite a redução das emissões ou até mesmo o aumento na remoção dos gases do efeito estufa.

Após a aprovação do projeto de MDL, a diminuição na emissão de gases passa a ser denominada como redução certificada de carbono (RCE) ou crédito de carbono.

\footnotetext{
21 CRUZ, Paulo Márcio; BODNAR, Zenildo. O clima como necessidade de governança
} transnacional: reflexões pós-Copenhague 2009. 
KEMPFER, Jéssica Cindy. A tributação das operações de crédito de carbono. Revista Eletrônica Direito e Política, Programa de Pós-Graduação Stricto Sensu em Ciência Jurídica da UNIVALI, Itajaí, v.11, n.3, $3^{\circ}$ quadrimestre de 2016. Disponível em: www.univali.br/direitoepolitica - ISSN 19807791.

Em razão da natureza comercial, a Redução Certificada de Carbono, que dá origem ao crédito de carbono, faz parte de um novo mercado de transações: o mercado de carbono, o qual significa qualquer transação comercial na compra e venda desse tipo de mercadoria.

A redução de emissões de Gases de Efeito Estufa (GEE) é medida em toneladas de dióxido de carbono equivalente. Cada tonelada de $\mathrm{CO} 2 \mathrm{e}$ reduzida ou removida da atmosfera corresponde a uma unidade emitida pelo Conselho Executivo do MDL, denominada de Redução Certificada de Emissão (RCE). Dessa forma, cada tonelada de $\mathrm{CO} 2$ equivale a 1 (um) crédito de carbono ${ }^{22}$.

A atribuição de valor ao resultado de esforços de redução das emissões da atmosfera culminou na criação de novos mercados para a negociação mundial das RCEs. Dessa forma criados mercados, tanto com o objetivo de atender a compromissos de redução de emissões negociadas no Protocolo de Kyoto, quanto mercados voluntários para a negociação destes títulos ${ }^{23}$.

Esses mercados são ambientes eletrônicos de negociação desenvolvidos para viabilizar, de forma ágil, segura e transparente, o fechamento de negócios com créditos gerados por projetos de Mecanismo de Desenvolvimento Limpo. As operações são realizadas por meio de leilões eletrônicos, via web, e agendados pela BM\&F Bovespa a pedido de entidades - públicas ou privadas - que desejem ofertar seus créditos de carbono no mercado ${ }^{24}$.

O funcionamento do mercado de créditos de carbono funciona da seguinte forma: um país pode ceder permissões às empresas para que elas possam emitir uma quantidade de GEEs. Se algumas dessas empresas utilizarem um nível igual

\footnotetext{
22 PORTAL BRASIL. Entenda como funciona o mercado de crédito de carbono. Disponível em: <http://www.brasil.gov.br/meio-ambiente/2012/04/entenda-como-funciona-o-mercado-decredito-de-carbono>. Acesso em: 29 mar. 2016.
}

23 INSTITUTO DE PESQUISA ECONÔMICA APLICADA. Sustentabilidade ambiental no Brasil: biodiversidade, economia e bem-estar humano. gráfs., mapas, tabs. (Série Eixos Estratégicos do Desenvolvimento Brasileiro; Sustentabilidade Ambiental. Livro 7. Brasília: Ipea, 2010. 640 p.

24 ALVES, Raíza Silva; OLIVEIRA, Louise Antunes de; LOPES, Paloma de Lavor. Crédito de Carbono: $O$ mercado de crédito de carbono no Brasil. Disponível em: <http://www.aedb.br/seget/arquivos/artigos13/2018412.pdf>. Acesso em: 29 mar. 2016. 
KEMPFER, Jéssica Cindy. A tributação das operações de crédito de carbono. Revista Eletrônica Direito e Política, Programa de Pós-Graduação Stricto Sensu em Ciência Jurídica da UNIVALI, Itajaí, v.11, n.3, $3^{\circ}$ quadrimestre de 2016. Disponível em: www.univali.br/direitoepolitica - ISSN 19807791.

ou abaixo das permissões acordadas, então o país poderá vender os créditos dessas permissões que restarem. Da mesma forma, se um país não for capaz de cumprir sua meta, poderá comprar Reduções Certificadas de Emissões de outros países que possuam créditos.

A comercialização das RCEs pode se dar em qualquer momento do projeto de MDL, isto é, desde sua elaboração (mercado de projetos) até as emissões das reduções certificadas de carbono (mercado de emissões). Essa compra e venda antecipada dos créditos de carbono não é ilegal, contudo, quanto mais no inicio do projeto forem comercializados, menor o seu valor ${ }^{25}$.

O mercado de carbono existente fora do contexto do Protocolo é denominado Mercado Voluntário, ou seja, ele acontece fora do contexto 'compulsório' do Protocolo de Kyoto. Ele conta com vários programas voluntários de redução das emissões sendo implementados ao redor do globo e seguindo o mesmo raciocínio de compensação das emissões utilizado no Mecanismo de Desenvolvimento Limpo tratado no Protocolo.

Essas negociações em ambientes voluntários são guiadas pelas regras comuns de mercado, podendo ser efetuadas em bolsas, através de intermediários ou diretamente entre as partes interessadas ${ }^{26}$.

Com o mercado voluntário, muitas empresas privadas estão internalizando voluntariamente o preço do carbono em suas atividades empresariais. Em 2014, foram comprados voluntariamente compensações de carbono equivalente a cerca de 87 milhões de toneladas métricas de CO2, um aumento de 14 por cento em relação ao ano anterior e esse número tende a subir ${ }^{27}$.

${ }^{25}$ LIMIRO. Créditos de Carbono: Protocolo de Kyoto e Projetos de MDL. p. 121-123.

26 INSTITUTO CARBONO BRASIL. Mercado de Carbono. Julho/2013. Disponível em: <http://www.institutocarbonobrasil.org.br/mercado_de_carbono>. Acesso em: 29 mar. 2016.

27 FOREST TRENDS. Voluntary Buyers Spend Nearly $\$ 4.5$ Billion on Offsets to Combat Climate Impacts. Disponível em: <http://foresttrends.org/releases/p/ahead_of_the_curve_state_of_the_voluntary_carbon_market s_2015>. Acesso em: 29 mar. 2016. 
KEMPFER, Jéssica Cindy. A tributação das operações de crédito de carbono. Revista Eletrônica Direito e Política, Programa de Pós-Graduação Stricto Sensu em Ciência Jurídica da UNIVALI, Itajaí, v.11, n.3, $3^{\circ}$ quadrimestre de 2016. Disponível em: www.univali.br/direitoepolitica - ISSN 19807791.

No mercado voluntário, os créditos de carbono podem ser gerados em qualquer lugar do mundo e são auditados por uma entidade independente do sistema das Nações Unidas ${ }^{28}$.

Atualmente, visto sob o aspecto de um mercado de balcão, o mercado de créditos de carbono é o espaço público em que se comercializam ativos de valor econômico, padronizados em qualidade e quantidade para a liquidez de sua circulação ${ }^{29}$.

Esse tipo de negociação tem atraído companhias com diferentes objetivos. Algumas se mostram preocupadas em reduzir as emissões de gases poluentes, não para atingirem eventuais metas estabelecidas, mas com o único intuito de gerarem créditos e, com isso, além de terem uma nova fonte de receitas, agregar valor a sua marca pela vinculação da ideia de "ser verde". Para essas empresas, a redução de emissão passa a ser vista como investimento e oportunidade e não como custo.

A comercialização das RCEs por empresas multinacionais se concretiza por intermédio do contrato internacional de compra e venda de créditos, também conhecido como ERPA ${ }^{30}$, o qual é acordo bilateral e é regido pelas leis do país onde foi proposto, conforme art. 90 da Lei de Introdução ao Código Civil Brasileiro (Lei 4.657/42).

O potencial brasileiro para a participação no mercado de carbono é grande. A participação brasileira no mercado de carbono não é maior ante a falta de regulamentação, fazendo com que grande parte das transações seja feita por meio de contratos de balcão ${ }^{31}$.

28 RETTMANN, Ricardo. O que é e como funciona o Mercado de Carbono? Disponível em: <http://ipam.org.br/cartilhas-ipam/o-que-e-e-como-funciona-o-mercado-de-carbono>. Acesso em: 19 abr. 2016.

\footnotetext{
${ }^{29}$ LORENZONI NETO. Contrato de Créditos de Carbono. p. 73.

${ }^{30}$ Em inglês Emission Reduction Purchase Agreement

${ }^{31}$ LIMIRO. Créditos de Carbono: Protocolo de Kyoto e Projetos de MDL. p. 129-130.
} 
KEMPFER, Jéssica Cindy. A tributação das operações de crédito de carbono. Revista Eletrônica Direito e Política, Programa de Pós-Graduação Stricto Sensu em Ciência Jurídica da UNIVALI, Itajaí, v.11, n.3, $3^{\circ}$ quadrimestre de 2016. Disponível em: www.univali.br/direitoepolitica - ISSN 19807791.

\subsection{A NATUREZA JURÍDICA DOS CRÉDITOS DE CARBONO}

Não obstante o crescente volume mundial de projetos de mecanismo de desenvolvimento limpo, assim como do comércio dos créditos de carbono decorrentes destes, o assunto ainda é cercado de incertezas acerca da natureza jurídica dos créditos de carbono.

O Protocolo de Kyoto não trouxe a definição jurídica da Redução Certificada de Carbono. Em vista disso, um projeto na Câmara de Deputados, proposto em 2007, define a natureza jurídica do crédito de carbono como um valor mobiliário, negociado na BM\&F (Bolsa de Mercadorias e Futuros), sob supervisão da Comissão de Valores Mobiliários (CVM) ${ }^{32}$.

Seguindo este entendimento, a lei que instituiu a Política Nacional sobre mudanças climáticas, Lei 12.187/2009, classifica a Redução Certificada de Carbono como título mobiliário.

Art. 90. O Mercado Brasileiro de Redução de Emissões MBRE será operacionalizado em bolsas de mercadorias e futuros, bolsas de valores e entidades de balcão organizado, autorizadas pela Comissão de Valores Mobiliários - CVM, onde se dará a negociação de títulos mobiliários representativos de emissões de gases de efeito estufa evitadas certificadas.

Contudo, ainda no ano de 2009, a Comissão de Valores Mobiliários (CVM) anunciou que o crédito de carbono não deve ser considerado um valor mobiliário ${ }^{33}$. Tal entendimento ficou demonstrado no voto de Otavio Yazbek, Diretor da Comissão de Valores Mobiliários.

32 CÂMARA DOS DEPUTADOS. Projeto de Lei n. 493, de 2007 (Apensado: Projeto de Lei no 594, de 2007). Dispõe sobre a organização e regulação do mercado de Carbono na Bolsa de Valores do Rio de Janeiro através da geração de Redução Certificada de Emissão - RCE em projetos de Mecanismo de Desenvolvimento Limpo - MDL. Disponível em: <http://www.camara.gov.br/proposicoesWeb/prop_mostrarintegra?codteor=444146\&filename $=$ P L+493/2007>. Acesso em: 19 abr. 2016.

33 MACHADO, Tatiana. A tributação no mercado de carbono. 2010. Disponível em: <www.cnc.org.br/sites/default/files/arquivos/dj3nov2010.pdf>. Acesso em: 19 abr. 2016. 
KEMPFER, Jéssica Cindy. A tributação das operações de crédito de carbono. Revista Eletrônica Direito e Política, Programa de Pós-Graduação Stricto Sensu em Ciência Jurídica da UNIVALI, Itajaí, v.11, n.3, $3^{\circ}$ quadrimestre de 2016. Disponível em: www.univali.br/direitoepolitica - ISSN 19807791.

Entendo, que os créditos de carbono não são instrumentos derivativos, não se thes podendo considerar como valores mobiliários para os fins dos incisos VII e VIII do art. $2^{\circ} \mathrm{da}$ Lei no 6.385/76. O fato é que, (i) não havendo a manutenção de vínculo, em razão da aquisição de uma RCE, entre $o$ adquirente desta e o agente econômico que implantou o projeto de $\mathrm{MDL}$; e (ii) não se destinando as RCEs a corporificar um investimento propriamente financeiro, não há que se falar na caracterização dos créditos de carbono em si como valores mobiliários ${ }^{34}$.

Há ainda quem considere as RCEs como uma commodity ${ }^{35}$, pois representariam uma mercadoria fungível individualizada em gênero e espécie e que, portanto, poderia ser substituída por outra da mesma natureza ${ }^{36}$.

Contudo, as operações de "sequestro de carbono" não se enquadram nessa definição, pois são entendidas como processo $^{37}$ em razão do grau de dependência que existe entre o certificado de emissão reduzida e o projeto de MDL, não há como classificá-lo como bem fungível e, portanto, como commodity.

O Banco Central do Brasil (Bacen), por outro lado, através da Circular no 3.291, de 08.09.2005, que alterou o Regulamento do Mercado de Câmbio e Capitais Internacionais, instituiu um canal de ingresso de recursos decorrentes do "crédito de carbono", classificando a RCE (Redução Certificada de Carbono) como serviço "Natureza da Operação: Serviços Diversos - Créditos de Carbono 29/(NR) - Código: 45500."

34 YAZBEK, Otavio. Voto do Diretor no processo administrativo CVM no RJ 2009/6346. Disponível em: <http://www.cvm.gov.br/export/sites/cvm/decisoes/anexos/0005/6565-0.pdf>. Acesso em: 19 abr. 2016.

35 Do inglês: "mercadoria". Expressão utilizada para designar bens e as vezes serviços para os quais existe procura sem diferenciação de qualidade do produto no conjunto dos mercados ou entre vários fornecedores ou marcas.

36 MACHADO. Tatiana. A tributação no mercado de carbono. 2010. Disponível em: <www.cnc.org.br/sites/default/files/arquivos/dj3nov2010.pdf>. Acesso em: 19 abr. 2016

37 MARQUES, Fernando R.; MAGALHÃES, Gerusa. Isenção tributária para os créditos de carbono. $292010 . \quad$ abr. 201 Disponível <http://www.cfc.org.br/conteudo.aspx?codMenu=67\&codConteudo=4643>. Acesso em: 19 abr. 2016. 
KEMPFER, Jéssica Cindy. A tributação das operações de crédito de carbono. Revista Eletrônica Direito e Política, Programa de Pós-Graduação Stricto Sensu em Ciência Jurídica da UNIVALI, Itajaí, v.11, n.3, 30 quadrimestre de 2016. Disponível em: www.univali.br/direitoepolitica - ISSN 19807791.

Contudo, pode-se dizer que o anfitrião do projeto de MDL não visa à prestação de um serviço, mas sim obter a certificação das suas reduções de emissão. 0 objeto do projeto de MDL (mecanismo de desenvolvimento limpo) é a geração do crédito de carbono e não a prestação de um serviço.

Ainda, para alguns, os créditos de carbono podem ser definidos como ativos financeiros ${ }^{38}$. Contudo, sabe-se que a RCE não possui uma existência física ou documental, trata-se de um ativo intangível e eletrônico, sendo, portanto, descabida qualquer pretensão de classificação como um ativo tangível (mercadoria) à luz do ordenamento jurídico brasileiro e internacional.

Atualmente, a doutrina jurídica pátria advoga a classificação latu sensu sobre o assunto. Depreende-se que a RCE possuiria a natureza jurídica de ativo incorpóreo ou intangível, pois, apesar de não possuir existência física ou cartular, ela representa um valor econômico, transacionável por meio de contratos de cessão, que deve ser reconhecido pelo Direito ${ }^{39}$.

Tal classificação se compreende exclusivamente no âmbito do regime jurídico brasileiro e tem o intuito de regulamentar a forma pela qual se tratarão as receitas decorrentes da comercialização e cessão dos créditos de carbono.

Um dos indicativos favoráveis a esse entendimento é o de que, apesar das incertezas do tema, a Receita Federal do Brasil entendeu que a comercialização da RCE se dá através da cessão de direito para o exterior ${ }^{40}$.

\footnotetext{
38 PLAZA, Charlene Maria Coradini de Ávila; SANTOS, Nivaldo dos Santos; FARIAS, Ludmilla Evelin. A natureza jurídica e contratual dos créditos de carbono e a aplicabilidade do direito tributário pátrio: Incertezas e indefinições. Anais do XVII Congresso Nacional do CONPEDI, Brasília/DF, 20, 21 e 22 de novembro de 2008.

39 MACHADO FILHO, Haroldo; SABBAG, Bruno Kerlakian. Classificação da natureza jurídica do crédito de carbono e defesa da isenção tributária total às receitas decorrentes da cessão de créditos de carbono como forma de aprimorar o combate ao aquecimento global. E-Gov. 2011. Disponível em: <http://www.egov.ufsc.br/portal/sites/default/files/anexos/32148-38095-1PB.pdf>. Acesso em: 19 abr. 2016.

40 Consulta Pública no 59/2008 da Delegacia Fiscal da 9a Região (PR e SC) que decidiu que sobre os valores percebidos com a comercialização da RCE incide o IRPJ, sendo isentos do PIS/Pasep e da Cofins os valores sobre a operação de cessão para o exterior.
} 
KEMPFER, Jéssica Cindy. A tributação das operações de crédito de carbono. Revista Eletrônica Direito e Política, Programa de Pós-Graduação Stricto Sensu em Ciência Jurídica da UNIVALI, Itajaí, v.11, n.3, $3^{\circ}$ quadrimestre de 2016. Disponível em: www.univali.br/direitoepolitica - ISSN 19807791.

Não é outro o pensamento de Werner Grau Neto, sócio da área de sustentabilidade e mudança do clima do escritório Pinheiro Neto Advogados e mestre e especialista em direito internacional pela Universidade de São Paulo (USP):

A ausência de fungibilidade e vinculação do certificado à atividade de MDL; a existência de equivalência monetária, e não obrigação pecuniária em si; e a inexistência de uma prestação de serviço, e sim a realização de uma cessão de crédito, são elementos a afastar a consideração do certificado como commodity, título mobiliário ou prestação de serviços ${ }^{41}$.

Diante de suas peculiaridades, verificou-se que as RCEs não possuem materialidade, mas sim, subsiste em cenário eletrônico. Dessa forma ao emitir as RCEs, as empresas criam ativos que devem ser escriturados em seus demonstrativos contábeis ${ }^{42}$.

Portanto necessária a análise da tributação incidente nas atividades de MDL.

\section{ASPECTOS TRIBUTÁRIOS DOS CRÉDITOS DE CARBONO}

Classificadas como bens intangíveis pelo direito brasileiro, as Reduções Certificadas de Emissões (RCEs) não possuem, dessa forma, legislação única que aborde tal assunto. Com isso, as normas gerais que podem tratar sobre a tributação incidente nas RCEs estão dispersas na legislação.

41 GRAU NETO, Werner. Questões pendentes do Protocolo de Kyoto. Disponível em: <http://infoener.iee.usp.br/infoener/hemeroteca/imagens/117152.htm>. Acesso em: 29 mar. 2016.

42 LOPES, Andréa Regina Ubeda; PORTUGAL, Heloisa Helena de Almeida; CARDOSO, Sérgio. Investimentos em Crédito de Carbono: Possibilidade de Incidência Tributária. Disponível em: <http://www.idtl.com.br/artigos/296.pdf>. Acesso em: 29 mar. 2016. 
KEMPFER, Jéssica Cindy. A tributação das operações de crédito de carbono. Revista Eletrônica Direito e Política, Programa de Pós-Graduação Stricto Sensu em Ciência Jurídica da UNIVALI, Itajaí, v.11, n.3, $3^{\circ}$ quadrimestre de 2016. Disponível em: www.univali.br/direitoepolitica - ISSN 19807791.

\subsection{TRIBUTAÇÃO SOBRE A CIRCULAÇÃO DAS REDUÇÕES CERTIFICADAS DE EMISSÕES}

Segundo o artigo 153, inciso I, da Constituição Republicana de 1988, compete à União instituir impostos sobre importação de produtos estrangeiros. Transcrevese do dispositivo:

Art. 153. Compete à União instituir impostos sobre:

I - importação de produtos estrangeiros;

Do latim productus, chama-se produto aquilo que tenha sido alvo de fabrico, ou seja, que tenha sido fabricado ou produzido. Portanto, produto, por possuir natureza física. Desse conjunto não fazem parte os bens de natureza incorpórea ou intangível.

Dessa forma, em suma, não há como haver ocorrência do fato gerador do imposto de importação (a entrada de produtos estrangeiros no território nacional) na emissão de RCEs.

Da mesma forma em que não é possível a incidência de imposto de importação, não se pode cogitar a incidência de imposto de exportação sobre tais negócios jurídicos, pois segundo o artigo 153, inciso II, da Constituição Republicana de 1988, compete à União instituir impostos sobre a exportação, para o exterior, de produtos nacionais ou nacionalizados e as RCEs não podem ser classificadas como tais.

Não sendo mercadoria, também não haverá incidência do ICMS e nem IPI.

\subsection{TRIBUTAÇÃO SOBRE AS RECEITAS AUFERIDAS COM REDUÇÕES CERTIFICADAS DE EMISSÕES}

As operações que envolvem RCEs resultam em ganho de capital para as empresas que as transmitem. Por esse motivo, nos tópicos seguintes serão analisados os tributos possivelmente incidentes nas receitas auferidas com a comercialização de RCEs. 
KEMPFER, Jéssica Cindy. A tributação das operações de crédito de carbono. Revista Eletrônica Direito e Política, Programa de Pós-Graduação Stricto Sensu em Ciência Jurídica da UNIVALI, Itajaí, v.11, n.3, 30 quadrimestre de 2016. Disponível em: www.univali.br/direitoepolitica - ISSN 19807791.

\subsubsection{CONTRIBUIÇÃo AO PROGRAMA DE INTEGRAÇÃo SOCIAL E DE FORMAÇÃO DO PATRIMÔNIO DO PODER PÚBLICO}

A Contribuição ao Programa de Integração Social e de Formação do Patrimônio do Servidor Público (Pis/Pasep), instituída pela Lei Complementar no 7 de 1970 e pela Lei Complementar n. 8 de 1970, possui previsão no art. 239 da Constituição Federal:

Art. 239 - A arrecadação decorrente das contribuições para o Programa de Integração Social, criado pela Lei Complementar no 7, de 7 de setembro de 1970, e para o Programa de Formação do Patrimônio do Servidor Público, criado pela Lei Complementar no 8, de 3 de dezembro de 1970, passa, a partir da promulgação desta Constituição, a financiar, nos termos que a lei dispuser, o programa do seguro-desemprego e 0 abono de que trata $0 \S 3^{\circ}$ deste artigo.

Esta contribuição tem como fatos geradores (1) o auferimento de receita pela pessoa jurídica de direito privado e as que Ihe são equiparadas pela legislação do imposto de renda; (2) a folha de salários das entidades relacionadas no art. 13 e das cooperativas que excluírem da receita qualquer dos itens enumerados no art. 15 da MP n 0 2.158-35, de 2001, e (3) as receitas correntes arrecadadas e as transferências correntes e de capital recebidas pelas pessoas jurídicas de direito público interno, exceto as fundações públicas (a partir de 12.02.2000, as fundações públicas passaram a contribuir para o PIS/Pasep com base na folha mensal de salário (MP n o 2.158-35, de 2001, art. 13, VIII).

A base de cálculo das contribuições devidas pelas pessoas jurídicas de direito privado, é o faturamento do mês, que corresponde à receita bruta. Assim, todas as pessoas jurídicas sujeitam-se à incidência do PIS/Pasep com base no lucro real, valendo destacar, neste ponto o art. $1^{\circ}$ da Lei 10.637/02:

Art. 10 A contribuição para o PIS/Pasep tem como fato gerador o faturamento mensal, assim entendido o total das receitas auferidas pela pessoa jurídica, independentemente de sua denominação ou classificação contábil.

$\S 10$ Para efeito do disposto neste artigo, o total das receitas compreende a receita bruta da venda de bens e serviços nas 
KEMPFER, Jéssica Cindy. A tributação das operações de crédito de carbono. Revista Eletrônica Direito e Política, Programa de Pós-Graduação Stricto Sensu em Ciência Jurídica da UNIVALI, Itajaí, v.11, n.3, $3^{\circ}$ quadrimestre de 2016. Disponível em: www.univali.br/direitoepolitica - ISSN 19807791.

operações em conta própria ou alheia e todas as demais receitas auferidas pela pessoa jurídica.

$\S 20$ A base de cálculo da contribuição para o PIS/Pasep é o valor do faturamento, conforme definido no caput.

Portanto, entende-se por receita bruta a totalidade das receitas auferidas, sendo irrelevantes o tipo de atividade exercida pela pessoa jurídica e a classificação contábil adotada para as receitas.

Traçado um panorama geral sobre o fato gerador e base de cálculo da contribuição Pis/Pasep, se faz necessário verificar a sua incidência no mercado de carbono.

Analisando a cessão de RCE, percebe-se que esta é, via de regra, onerosa, havendo contraprestação a ser paga ao titular da Redução Certificada de Emissão (RCE), uma vez que é inclusive comercializada em bolsas de valores.

Tal contraprestação representa o ingresso de receita a pessoa jurídica cedente da $\mathrm{RCE}$, traduzida por algo que se agrega ao seu patrimônio. Portanto, é possível afirmar que a cessão onerosa de RCE pela pessoa jurídica que as detém enseja a incidência da contribuição ao Pis/Pasep no exato momento do recebimento da contraprestação.

Contudo, embora a cessão gere a incidência da contribuição em exame, o art. 30, parágrafo segundo, inciso IV e o parágrafo único do art. 16 da Lei no 10.833/2003, excluem da base de cálculo do Pis/Pasep a venda de ativos permanentes. Dessa forma, desde que a pessoa jurídica cedente não tenha a intenção de alienar a RCE no curto prazo e, portanto, possa contabilizá-la como ativo permanente, as receitas dela decorrentes não devem integrar a base de cálculo do Pis/Pasep ${ }^{43}$.

Cumpre ressaltar que embora a possibilidade de incidência, a Superintendência da Receita Federal do Brasil da 9a Região Fiscal (Paraná e Santa Catarina), no

\footnotetext{
${ }^{43}$ SISTER, Gabriel. Mercado de Carbono e Protocolo de Quioto: Aspectos Negociais e Tributação. São Paulo: Campus Jurídico, 2008, p. 115.
} 
KEMPFER, Jéssica Cindy. A tributação das operações de crédito de carbono. Revista Eletrônica Direito e Política, Programa de Pós-Graduação Stricto Sensu em Ciência Jurídica da UNIVALI, Itajaí, v.11, n.3, $3^{\circ}$ quadrimestre de 2016. Disponível em: www.univali.br/direitoepolitica - ISSN 19807791.

processo de consulta no 59/2008 (DOU de 07.04.2008) sustentou haver uma isenção do Pis/Pasep nas cessões de créditos de carbono ao exterior.

Tal entendimento possui assento no art. 149, parágrafo segundo, inciso I da Constituição Federal de 1988, valendo transcrever:

Art. 149 - Compete exclusivamente à União instituir contribuições sociais, de intervenção no domínio econômico e de interesse das categorias profissionais ou econômicas, como instrumento de sua atuação nas respectivas áreas, observado o disposto nos arts. 146, III, e 150, I e III, e sem prejuízo do previsto no Art. $195, \S 6^{\circ}$, relativamente às contribuições a que alude o dispositivo.

$[\ldots]$

$\S 20$ As contribuições sociais e de intervenção no domínio econômico de que trata o caput deste artigo: I - não incidirão sobre as receitas decorrentes de exportação [...]

Pode-se dizer que o art. 149 da Constituição Federal estabelece uma hipótese de imunidade tributária, assim, mesmo que abstratamente a receita decorrente da cessão representasse um ingresso tributável, não há, no caso, a incidência do tributo.

Portanto, o ingresso de receita decorrente da cessão do crédito de carbono ao exterior é imune à tributação da contribuição PIS/Pasep, sendo apenas tributável, cessões realizadas internamente.

\subsubsection{CONTRIBUIÇÃO PARA O FINANCIAMENTO DA SEGURIDADE SOCIAL (COFINS)}

A autorização constitucional para a criação da Contribuição para o Financiamento da Seguridade Social está centrada no inciso I do artigo 195 da Constituição Federal (CF). No plano infraconstitucional, a Cofins foi instituída pela Lei Complementar no 70 de 30/12/1991 e atualmente, é regida pela Lei 9.718/98, ressalvadas as alterações subsequentes. 
KEMPFER, Jéssica Cindy. A tributação das operações de crédito de carbono. Revista Eletrônica Direito e Política, Programa de Pós-Graduação Stricto Sensu em Ciência Jurídica da UNIVALI, Itajaí, v.11, n.3, $3^{\circ}$ quadrimestre de 2016. Disponível em: www.univali.br/direitoepolitica - ISSN 19807791.

Trata-se de uma contribuição em nível federal calculada sobre a receita bruta de empresas. Sua arrecadação é destinada aos fundos de previdência e assistência social e da saúde pública.

A hipótese de incidência da Cofins encontra previsão no art. $1^{0}$ da Lei no 10.833.

Art. $1^{0}$ A Contribuição para o Financiamento da Seguridade Social - COFINS, com a incidência não-cumulativa, tem como fato gerador o faturamento mensal, assim entendido o total das receitas auferidas pela pessoa jurídica, independentemente de sua denominação ou classificação contábil.

$\S 10$ Para efeito do disposto neste artigo, o total das receitas compreende a receita bruta da venda de bens e serviços nas operações em conta própria ou alheia e todas as demais receitas auferidas pela pessoa jurídica.

$\S 20$ A base de cálculo da contribuição é o valor do faturamento, conforme definido no caput.

Embora se possa pensar que a Cofins incide sobre a receita auferida com a cessão das RCEs, tal não é o entendimento do Fisco. A Secretaria da Receita Federal em consulta assim decidiu:

Contribuição para o Financiamento da Seguridade Social - Cofins CREDITO DE CARBONO. CESSAO DE DIREITOS AO EXTERIOR.

Não estão sujeitas a tributação pela Cofins as receitas decorrentes da cessão de direitos relativos a créditos de carbono a pessoa física ou jurídica residente ou domiciliada no exterior, cujo pagamento represente ingresso de divisas. Dispositivos Legais: CF art. 149, $\S 20$, I; Lei no 10.833, de 2003, art. 60, II; MP N 2.158, de 2001, art. 14, III. (Solução de consulta no 475, 15 de dezembro de 2009).

Como mencionado no item anterior, tratando-se de contribuição social, como a PIS/Pasep, a Cofins sobre a exportação possui imunidade tributária, nos termos do art. 149, parágrafo segundo, inciso I da CF. 
KEMPFER, Jéssica Cindy. A tributação das operações de crédito de carbono. Revista Eletrônica Direito e Política, Programa de Pós-Graduação Stricto Sensu em Ciência Jurídica da UNIVALI, Itajaí, v.11, n.3, $3^{\circ}$ quadrimestre de 2016. Disponível em: www.univali.br/direitoepolitica - ISSN 19807791.

Embora os créditos de carbono tenham sido idealizados para o comércio (alienação) no exterior, nada impede o comércio interno. Portanto, excepcionalmente, se o comércio ocorrer internamente, a imunidade tributária estará afastada.

\subsection{TRIBUTAÇÃO SOBRE O LUCRO E RENDIMENTOS AUFERIDOS COM REDUÇÕES CERTIFICADAS DE EMISSÕES}

Sendo as RCEs bens intangíveis, os negócios jurídicos com tais bens poderão gerar para o transmitente o auferimento de ganho de capital tributável. Por esse motivo, seguem algumas discussões fundamentadas sobre a incidência de tributação sobre o lucro e rendimentos auferidos na comercialização deste título.

\subsubsection{IMPOSTO SOBRE A RENDA E PROVENTOS DE QUALQUER NATUREZA (IR)}

O imposto de renda e proventos, nos termos do artigo 153, III da Constituição Federal, é de competência privativa da União. As normas gerais deste tributo estão no art. 43 do Código Tributário Nacional:

Art. 43. O imposto, de competência da União, sobre a renda e proventos de qualquer natureza tem como fato gerador a aquisição da disponibilidade econômica ou jurídica:

I - de renda, assim entendido o produto do capital, do trabalho ou da combinação de ambos;

II - de proventos de qualquer natureza, assim entendidos os acréscimos patrimoniais não compreendidos no inciso anterior.

$\S 10$ A incidência do imposto independe da denominação da receita ou do rendimento, da localização, condição jurídica ou nacionalidade da fonte, da origem e da forma de percepção. (Incluído pela Lcp no 104, de 2001)

$\S 20 \mathrm{Na}$ hipótese de receita ou de rendimento oriundos do exterior, a lei estabelecerá as condições e o momento em 
KEMPFER, Jéssica Cindy. A tributação das operações de crédito de carbono. Revista Eletrônica Direito e Política, Programa de Pós-Graduação Stricto Sensu em Ciência Jurídica da UNIVALI, Itajaí, v.11, n.3, $3^{\circ}$ quadrimestre de 2016. Disponível em: www.univali.br/direitoepolitica - ISSN 19807791.

que se dará sua disponibilidade, para fins de incidência do imposto referido neste artigo. (Incluído pela Lcp no 104, de 2001).

Percebe-se pela leitura do artigo supracitado que a incidência do imposto corresponde à aquisição de renda auferida a partir de proventos de qualquer natureza que se amoldem ao conceito de acréscimo patrimonial.

Conforme artigo 45 do $\mathrm{CTN}^{44}$, o contribuinte, pessoa física ou jurídica, é o titular da renda ou proventos de qualquer natureza que gerem acréscimo patrimonial e responsável pelo cálculo, retenção e pagamento do imposto em comento.

A base de cálculo do imposto de renda é, conforme art. 44 do CTN ${ }^{45}$, o montante real, arbitrado ou presumido da renda ou proventos tributáveis. Dessa forma, para as pessoas jurídicas é o lucro que pode ser real, presumido ou arbitrado, correspondente ao período de apuração. Já para as pessoas físicas é, de forma geral, a diferença entre as somas de todos os rendimentos percebidos ao longo do ano.

Sabendo as características do tributo, resta analisar sua possível incidência no mercado de carbono, ressaltando que a incidência do IR varia entre pessoas físicas e jurídicas.

Muito embora seja sabido que a atuação (ou possível atuação) de pessoas físicas no mercado de carbono seja diminuta, inexiste qualquer impedimento à implantação do projeto de MDL ou ao comércio da RCE por pessoas naturais.

Portanto há de se analisar a incidência de IR pessoa física nas operações de crédito de carbono. Nesse ponto, importante ressaltar que as operações de carbono possuem, após a implementação do projeto, duas fases principais: a emissão da RCE e a cessão onerosa deste título.

\footnotetext{
${ }^{44}$ Art. 45. Contribuinte do imposto é o titular da disponibilidade a que se refere o artigo 43, sem prejuízo de atribuir a lei essa condição ao possuidor, a qualquer título, dos bens produtores de renda ou dos proventos tributáveis.

45 Art. 44. A base de cálculo do imposto é o montante, real, arbitrado ou presumido, da renda ou dos proventos tributáveis.
} 
KEMPFER, Jéssica Cindy. A tributação das operações de crédito de carbono. Revista Eletrônica Direito e Política, Programa de Pós-Graduação Stricto Sensu em Ciência Jurídica da UNIVALI, Itajaí, v.11, n.3, $3^{\circ}$ quadrimestre de 2016. Disponível em: www.univali.br/direitoepolitica - ISSN 19807791.

A emissão da RCE, por ser, a priori, questão afeta ao Conselho Executivo, é negócio jurídico atípico e não gera qualquer tipo de renda ou proventos, mas apenas a simples incorporação do ativo ao patrimônio do titular do projeto. Por esse motivo, não há concretização da hipótese de incidência do IR.

No que diz respeito à cessão onerosa da RCE a legislação ordinária como anteriormente disposto, quando trata a respeito da incidência de imposto de renda, abrange toda e qualquer forma de obtenção de rendimentos, proventos e ganhos, inclusive aqueles localizados em outras jurisdições.

Nesse sentido, o artigo $3^{\circ}$ da Lei no 7.713/88:

Art. $3^{\circ} 0$ imposto incidirá sobre o rendimento bruto, sem qualquer dedução, ressalvado o disposto nos arts. 90 a 14 desta Lei. (Vide Lei 8.023, de 12.4.90)

$\S 10$ Constituem rendimento bruto todo o produto do capital, do trabalho ou da combinação de ambos, os alimentos e pensões percebidos em dinheiro, e ainda os proventos de qualquer natureza, assim também entendidos os acréscimos patrimoniais não correspondentes aos rendimentos declarados.

$\S 20$ Integrará o rendimento bruto, como ganho de capital, o resultado da soma dos ganhos auferidos no mês, decorrentes de alienação de bens ou direitos de qualquer natureza, considerando-se como ganho a diferença positiva entre $o$ valor de transmissão do bem ou direito e o respectivo custo de aquisição corrigido monetariamente, observado o disposto nos arts. 15 a 22 desta Lei.

$\S 30 \mathrm{Na}$ apuração do ganho de capital serão consideradas as operações que importem alienação, a qualquer título, de bens ou direitos ou cessão ou promessa de cessão de direitos à sua aquisição, tais como as realizadas por compra e venda, permuta, adjudicação, desapropriação, dação em pagamento, doação, procuração em causa própria, promessa de compra e venda, cessão de direitos ou promessa de cessão de direitos e contratos afins.

$\S 40$ A tributação independe da denominação dos rendimentos, títulos ou direitos, da localização, condição jurídica ou nacionalidade da fonte, da origem dos bens produtores da renda, e da forma de percepção das rendas ou proventos, bastando, para a incidência do imposto, o 
KEMPFER, Jéssica Cindy. A tributação das operações de crédito de carbono. Revista Eletrônica Direito e Política, Programa de Pós-Graduação Stricto Sensu em Ciência Jurídica da UNIVALI, Itajaí, v.11, n.3, $3^{\circ}$ quadrimestre de 2016. Disponível em: www.univali.br/direitoepolitica - ISSN 19807791.

benefício do contribuinte por qualquer forma e a qualquer título.

$\S 50$ Ficam revogados todos os dispositivos legais concessivos de isenção ou exclusão, da base de cálculo do imposto de renda das pessoas físicas, de rendimentos e proventos de qualquer natureza, bem como os que autorizam redução do imposto por investimento de interesse econômico ou social.

$\S 60$ Ficam revogados todos os dispositivos legais que autorizam deduções cedulares ou abatimentos da renda bruta do contribuinte, para efeito de incidência do imposto de renda.

Portanto, como se pode notar, as operações de cessão de direito que resultarem na apuração de ganho de capital deverão integrar os rendimentos brutos daquele que a aufere e, portanto, integrar a base de cálculo do imposto de renda.

O ganho de capital é aferido pela diferença entre o valor de transmissão e o custo da aquisição que, no caso da RCE, seria o dispêndio para a emissão do título e incluiria, igualmente, as despesas com a implementação do projeto de MDL. Assim, tal custo deve constar na declaração de IR juntamente com o número de Reduções Certificadas de Emissão recebidas.

Relativamente ao Imposto de Renda Pessoa Jurídica, o artigo 31 do Decreto Lei no $1.598 / 77$, alterado em parte pela Lei no $12.973 / 2014$, assim dispõe:

Art. 31. Serão classificados como ganhos ou perdas de capital, e computados na determinação do lucro real, os resultados na alienação, inclusive por desapropriação $\left(\S 4^{\circ}\right)$, na baixa por perecimento, extinção, desgaste, obsolescência ou exaustão, ou na liquidação de bens do ativo não circulante, classificados como investimentos, imobilizado ou intangível. (Redação dada pela Lei no 12.973, de 2014)

$\S 1^{\circ}$ Ressalvadas as disposições especiais, a determinação do ganho ou perda de capital terá por base o valor contábil do bem, assim entendido o que estiver registrado na escrituração do contribuinte, diminuído, se for o caso, da depreciação, amortização ou exaustão acumulada e das perdas estimadas no valor de ativos. (Redação dada pela Lei no 12.973 , de 2014) 
KEMPFER, Jéssica Cindy. A tributação das operações de crédito de carbono. Revista Eletrônica Direito e Política, Programa de Pós-Graduação Stricto Sensu em Ciência Jurídica da UNIVALI, Itajaí, v.11, n.3, 30 quadrimestre de 2016. Disponível em: www.univali.br/direitoepolitica - ISSN 19807791.

$\S 2^{\circ}$ Nas vendas de bens do ativo não circulante classificados como investimentos, imobilizado ou intangível, para recebimento do preço, no todo ou em parte, após o término do exercício social seguinte ao da contratação, o contribuinte poderá, para efeito de determinar o lucro real, reconhecer o lucro na proporção da parcela do preço recebida em cada período de apuração. (Redação dada pela Lei no 12.973, de 2014)

$\S 40$ - O contribuinte poderá diferir a tributação do ganho de capital na alienação de bens desapropriados, desde que:

a) o transfira para reserva especial de lucros;

b) aplique, no prazo máximo de 2 anos do recebimento da indenização, na aquisição de outros bens do ativo permanente, importância igual ao ganho de capital;

c) discrimine, na reserva de lucros, os bens objeto da aplicação de que trata a letra $b$, em condições que permitam a determinação do valor realizado em cada período.

$\S 50$ - A reserva de que trata o parágrafo anterior será computada na determinação do lucro real nos termos do § 10 do artigo 35, ou utilizados para distribuição de dividendos.

$\S 6^{\circ}$ A parcela de depreciação anteriormente excluída do lucro líquido na apuração do lucro real deverá ser adicionada na apuração do imposto no período de apuração em que ocorrer a alienação ou baixa do ativo. (Incluído pela Lei $\mathrm{n}^{\mathrm{o}}$ 12.973, de 2014)

$\S 7^{\circ}$ A Secretaria da Receita Federal do Brasil, no âmbito de suas atribuições, disciplinará o disposto neste artigo.

No caso das cessões onerosas das Reduções Certificadas de Emissão, se o valor recebido em razão da celebração do negócio jurídico for superior ao valor contábil das RCEs, registradas na contabilidade da pessoa jurídica, haverá a incidência do imposto de renda. O valor contábil de tal bem seria formado por meio das despesas que a pessoa jurídica incorreu para a sua emissão.

Portanto, ganhos patrimoniais auferidos com a cessão onerosa da RCE deverão sujeitar-se à incidência de IR pessoa jurídica. 
KEMPFER, Jéssica Cindy. A tributação das operações de crédito de carbono. Revista Eletrônica Direito e Política, Programa de Pós-Graduação Stricto Sensu em Ciência Jurídica da UNIVALI, Itajaí, v.11, n.3, 30 quadrimestre de 2016. Disponível em: www.univali.br/direitoepolitica - ISSN 19807791.

\subsubsection{CONTRIBUIÇÃO SOCIAL SOBRE O LUCRO LÍQUIDO (CSLL)}

A Contribuição Social sobre o Lucro Líquido (CSLL) foi instituída pela Lei no 7.689/1988. Essa contribuição possui assento no art. 149 da Constituição Federal ${ }^{46}$ e tem como objetivo financiar a seguridade social.

Segundo o art. $2^{\circ}$ da Lei no $7.689 / 88^{47}$, a CSLL deve incidir sobre o resultado do exercício, antes da provisão para o imposto de renda. Vale destacar que se aplicam à CSLL as mesmas normas de apuração e de pagamento estabelecidas para o imposto de renda das pessoas jurídicas, mantidas a base de cálculo e as

\footnotetext{
${ }^{46}$ Art. 149. Compete exclusivamente à União instituir contribuições sociais, de intervenção no domínio econômico e de interesse das categorias profissionais ou econômicas, como instrumento de sua atuação nas respectivas áreas, observado o disposto nos arts. 146, III, e 150, I e III, e sem prejuízo do previsto no art. $195, \S 6^{\circ}$, relativamente às contribuições a que alude 0 dispositivo.

$\S 10$ Os Estados, o Distrito Federal e os Municípios instituirão contribuição, cobrada de seus servidores, para o custeio, em benefício destes, do regime previdenciário de que trata o art. 40, cuja alíquota não será inferior à da contribuição dos servidores titulares de cargos efetivos da União.
}

$\S 2^{\circ}$ As contribuições sociais e de intervenção no domínio econômico de que trata o caput deste artigo:

I - não incidirão sobre as receitas decorrentes de exportação;

II - incidirão também sobre a importação de produtos estrangeiros ou serviços;

III - poderão ter alíquotas:

a) ad valorem, tendo por base o faturamento, a receita bruta ou o valor da operação e, no caso de importação, o valor aduaneiro;

b) específica, tendo por base a unidade de medida adotada.

$\S 3^{\circ} \mathrm{A}$ pessoa natural destinatária das operações de importação poderá ser equiparada a pessoa jurídica, na forma da lei.

$\S 4^{\circ}$ A lei definirá as hipóteses em que as contribuições incidirão uma única vez.

${ }^{47}$ Art. $2^{\circ} \mathrm{A}$ base de cálculo da contribuição é o valor do resultado do exercício, antes da provisão para o imposto de renda. [...] 
KEMPFER, Jéssica Cindy. A tributação das operações de crédito de carbono. Revista Eletrônica Direito e Política, Programa de Pós-Graduação Stricto Sensu em Ciência Jurídica da UNIVALI, Itajaí, v.11, n.3, $3^{\circ}$ quadrimestre de 2016. Disponível em: www.univali.br/direitoepolitica - ISSN 19807791.

alíquotas previstas na legislação em vigor, conforme artigo 57 da Lei no $8.981 / 95^{48}$.

Dessa forma, apenas incidirá a Contribuição Social sobre o Lucro Líquido quando incidir, igualmente, imposto de renda, ou seja, apenas quando houver incremento ao patrimônio da pessoa jurídica, cessionária da RCE. Assim, aplicável o mesmo entendimento do item anterior.

\section{CONSIDERAÇÕES FINAIS}

Referenciou-se neste artigo que o desenvolvimento econômico de uma região em grande parte pode gerar impactos negativos na preservação ambiental ${ }^{49}$. Em vista disso, a partir do último século a comunidade internacional começou a se preocupar com questões relacionadas diretamente com o clima e meio ambiente. Assim restou firmado a Convenção-Quadro das Nações Unidas sobre mudanças do clima, com o objetivo principal de estabilizar as concentrações dos gases de efeito estufa na atmosfera.

A partir daí, foi criado o Protocolo de Kyoto, que traz em seu corpo uma série de políticas e medidas nacionais para mitigação dos efeitos negativos da mudança climática como metas de redução de emissões compulsórias de gases poluentes, criando também o instituto denominado como Redução Certificada de Emissões, que formarão os créditos de carbono, como incentivo para a redução dos impactos ambientais causados pela expansão acelerada da economia.

A redução certificada de Carbono, que dá origem ao crédito de carbono, faz parte de um novo mercado de transações: o mercado de carbono. O protocolo de

\footnotetext{
48 Art. 57. Aplicam-se à Contribuição Social sobre o Lucro (Lei no 7.689, de 1988) as mesmas normas de apuração e de pagamento estabelecidas para o imposto de renda das pessoas jurídicas, inclusive no que se refere ao disposto no art. 38, mantidas a base de cálculo e as alíquotas previstas na legislação em vigor, com as alterações introduzidas por esta Lei.

49 STAFFEN, Márcio Ricardo; ZAMBAM, Neuro José. Direito global e desigualdades: um estudo a partir do "direito dos povos" de John Rawls. Revista Eletrônica do Curso de Direito da UFSM, v. 10, n. 1, p. 243-258, 2015.
} 
KEMPFER, Jéssica Cindy. A tributação das operações de crédito de carbono. Revista Eletrônica Direito e Política, Programa de Pós-Graduação Stricto Sensu em Ciência Jurídica da UNIVALI, Itajaí, v.11, n.3, $3^{\circ}$ quadrimestre de 2016. Disponível em: www.univali.br/direitoepolitica - ISSN 19807791.

Kyoto lançou as bases para esse novo mercado que, atualmente, existe também fora do contexto do protocolo, contando com programas voluntários de redução das emissões.

Com a evolução desse mercado e, ainda, com o grande potencial brasileiro na participação, torna-se imprescindível a definição em torno da conceituação jurídica desses créditos. Percebeu-se que, até o momento, nenhum país do globo definiu a natureza jurídica stricto sensu das reduções certificadas de carbono. A doutrina jurídica pátria advoga a classificação latu sensu sobre o assunto, classificando a RCE como ativo incorpóreo ou intangível, pois, embora não exista em forma física ou cártula, representa um valor econômico, que pode ser comercializado tanto por pessoas físicas ou jurídicas domiciliadas no exterior como domiciliadas no Brasil.

Relativamente à tributação, considerando a classificação latu sensu das RCEs, como bens incorpóreos ou intangíveis, não há como haver ocorrência do fato gerador do imposto de exportação ou importação. Da mesma forma, por não se tratar tal bem jurídico de mercadoria, igualmente não haverá incidência do ICMS e tampouco do IPI.

O PIS/PASEP e a COFINS em operações de créditos de carbono que envolvam adquirentes no exterior estão imunes por força do art. 149, §20, inciso I da Constituição Federal. Se a cessão das RCEs é feita internamente, a imunidade tributária estará afastada.

Contudo, as operações que envolvem RCEs resultam em ganho de capital para as pessoas físicas ou jurídicas que as transmitem. Por esse motivo, atraem a tributação do Imposto de Renda e da Contribuição Social sobre o Lucro Líquido. Para este tipo de tributo é irrelevante se o adquirente é domiciliado no Brasil ou no exterior.

\section{REFERÊNCIAS DAS FONTES CITADAS}

ACCIOLY, Hildebrando; CASELLA, Paulo Borba; SILVA, G.E. do Nascimento e. Manual de Direito Internacional Público. 19. ed. São Paulo: Saraiva, 2011. 
KEMPFER, Jéssica Cindy. A tributação das operações de crédito de carbono. Revista Eletrônica Direito e Política, Programa de Pós-Graduação Stricto Sensu em Ciência Jurídica da UNIVALI, Itajaí, v.11, n.3, $3^{\circ}$ quadrimestre de 2016. Disponível em: www.univali.br/direitoepolitica - ISSN 19807791.

ALVES, Raíza Silva; OLIVEIRA, Louise Antunes de; LOPES, Paloma de Lavor. CRÉDITO DE CARBONO: O mercado de crédito de carbono no Brasil. Disponível em: <http://www.aedb.br/seget/arquivos/artigos13/2018412.pdf>. Acesso em: 29 mar. 2016.

CÂMARA DOS DEPUTADOS. Projeto de Lei n. 493, de 2007 (Apensado: Projeto de Lei no 594, de 2007). Dispõe sobre a organização e regulação do mercado de Carbono na Bolsa de Valores do Rio de Janeiro através da geração de Redução Certificada de Emissão - RCE em projetos de Mecanismo de Desenvolvimento Limpo - MDL. Disponível em: <http://www.camara.gov.br/proposicoesWeb/prop_mostrarintegra?codteor $=444$ 146\&filename $=P L+493 / 2007>$. Acesso em: 19 abr. 2016.

Disponível

Constituição da República Federativa do Brasil de 1988. $<$ http://www planalto gov br/ccivil 03/Constituicao/ConstituicaoCompilado htm. >. Acesso em: 07 jun. 2016.

Convenção-Quadro das Nações Unidas sobre Mudança do Clima. Decreto 2.652 de 01.07.1998. Disponível em: <http://www.mma.gov.br/clima/convencao-das-nacoes-unidas>. Acesso em: 07 jun. 2016.

CRUZ, Paulo Márcio; BODNAR, Zenildo. O clima como necessidade de governança transnacional: reflexões pós-Copenhague 2009. Seqüência: Estudos Jurídicos e Políticos, Florianópolis, p. 319-339, nov. 2010. ISSN 2177$7055 . \quad$ Disponível em: <https://periodicos. ufsc.br/index.php/sequencia/article/view/2177-7055.2010v31n60p319/15391>. Acesso em: 11 set. 2016.

Decisão 17/CP.7. Modalidades e procedimentos do Mecanismo de Desenvolvimento Limpo, conforme definido no artigo 12 do Protocolo de Quioto. 8a reunião plenária 10 de novembro de 2001. Disponível em: <http://www.mct.gov.br/upd_blob/0012/12919.pdf>. Acesso em: 19 abr. 2016.

Decreto n. 5455, de 12 de maio de 2005. Promulga o Protocolo de Quioto à Convenção-Quadro das Nações Unidas sobre Mudança do Clima, aberto a assinaturas na cidade de Quioto, Japão, em 11 de dezembro de 1997, por ocasião da Terceira Conferência das Partes da Convenção-Quadro das Nações Unidas sobre Mudança do Clima. Disponível em: <http://www.planalto.gov.br/ccivil_03/_Ato2004-

2006/2005/Decreto/D5445.htm>. Acesso em: 07 jun. 2016.

DINIZ, Eliezer Martins. Lessons from the Kyoto Protocol. 2007. Disponível em: <http://www.scielo.br/scielo.php? script=sci_arttext\&pid=S1414753X2007000100003\&lang=pt>. Acesso em: $21 \mathrm{fev} .2016$.

ETTMANN, Ricardo. O que é e como funciona o Mercado de Carbono? Disponível em: <http://ipam.org.br/cartilhas-ipam/o-que-e-e-como-funciona-omercado-de-carbono>. Acesso em: 19 abr. 2016. 
KEMPFER, Jéssica Cindy. A tributação das operações de crédito de carbono. Revista Eletrônica Direito e Política, Programa de Pós-Graduação Stricto Sensu em Ciência Jurídica da UNIVALI, Itajaí, v.11, n.3, $3^{\circ}$ quadrimestre de 2016. Disponível em: www.univali.br/direitoepolitica - ISSN 19807791.

FOREST TRENDS. Voluntary Buyers Spend Nearly \$4.5 Billion on Offsets to Combat Climate Impacts. Disponível em: <http://foresttrends.org/releases/p/ahead_of_the_curve_state_of_the_voluntary _carbon_markets_2015>. Acesso em: 29 mar. 2016.

FRANGETTO, Flavia Witkowski; GAZINI, Flávio Rufino. Viabilização Jurídica do Mecanismo de Desenvolvimento Limpo (MDL) no Brasil - O Protocolo de Quioto e a Cooperação Internacional. São Paulo: IIEB - Instituto Internacional de Educação do Brasil, 2002. p.30.

GRAU NETO, Werner. Questões pendentes do Protocolo de Kyoto. Disponível em: <http://infoener.iee.usp.br/infoener/hemeroteca/imagens/117152.htm>. Acesso em: 29 mar. 2016.

INSTITUTO CARBONO BRASIL. Mercado de Carbono. Julho/2013. Disponível em: <http://www.institutocarbonobrasil.org.br/mercado_de_carbono>. Acesso em: 29 mar. 2016.

INSTITUTO DE PESQUISA ECONÔMICA APLICADA. Sustentabilidade ambiental no Brasil: biodiversidade, economia e bem-estar humano. gráfs., mapas, tabs. (Série Eixos Estratégicos do Desenvolvimento Brasileiro; Sustentabilidade Ambiental. Livro 7. Brasília: Ipea, 2010. 640 p.

. Lei no 5.172, de 25 de outubro de 1966. Código Tributário Nacional. Dispõe sobre o Sistema Tributário Nacional e institui normas gerais de direito tributário aplicáveis à União, Estados e Municípios. Disponível em: <http://www.planalto.gov.br/ccivil_03/leis/I5172.htm>. Acesso em: 07 jun. 2016.

Lei no 6.385, de 7 de dezembro de 1976. Dispõe sobre o mercado de valores mobiliários e cria a Comissão de Valores Mobiliários. Disponível em: <http://www.planalto.gov.br/ccivil_03/leis/l6385.htm>. Acesso em: 19 abr. 2016.

Lei no 12.187, de 29 de dezembro de 2009. Institui a Política Nacional sobre Mudança do Clima - PNMC e dá outras providências. Disponível em: <http://www.planalto.gov.br/ccivil_03/_ato20072010/2009/lei/l12187.htm>. Acesso em: 19 abr. 2013.

LIMIRO, Danielle. Créditos de Carbono: Protocolo de Kyoto e Projetos de MDL. Curitiba: Juruá, 2012.

LOPES, Andréa Regina Ubeda; PORTUGAL,Heloisa Helena de Almeida; CARDOSO, Sérgio. Investimentos em Crédito de Carbono: Possibilidade de Incidência Tributária. Disponível em: <http://www.idtl.com.br/artigos/296.pdf>. Acesso em: 29 mar. 2016.

LOREnZONi NETO, Antonio. Contrato de Créditos de Carbono. Curitiba: Juruá, 2012. p. 21. 
KEMPFER, Jéssica Cindy. A tributação das operações de crédito de carbono. Revista Eletrônica Direito e Política, Programa de Pós-Graduação Stricto Sensu em Ciência Jurídica da UNIVALI, Itajaí, v.11, n.3, $3^{\circ}$ quadrimestre de 2016. Disponível em: www.univali.br/direitoepolitica - ISSN 19807791.

MACHADO FILHO, Haroldo; SABBAG, Bruno Kerlakian. Classificação da natureza jurídica do crédito de carbono e defesa da isenção tributária total às receitas decorrentes da cessão de créditos de carbono como forma de aprimorar o combate ao aquecimento global. E-Gov. 2011. Disponível em:

<http://www.egov.ufsc.br/portal/sites/default/files/anexos/32148-38095-1PB.pdf>. Acesso em: 26 ago. 2013.

MACHADO, Tatiana. A tributação no mercado de carbono. 2010. Disponível em: <www.cnc.org.br/sites/default/files/arquivos/dj3nov2010.pdf>. Acesso em: 19 abr. 2016.

MARQUES, Fernando R.; MAGALHÃES, Gerusa. Isenção tributária para os créditos de carbono. 29 abr. 2010. Disponível em: <http://www.cfc.org.br/conteudo.aspx?codMenu=67\&codConteudo=4643>. Acesso em: 19 abr. 2016.

PLAZA, Charlene Maria Coradini de Ávila; SANTOS, Nivaldo dos Santos; FARIAS, Ludmilla Evelin. A natureza jurídica e contratual dos créditos de carbono e a aplicabilidade do direito tributário pátrio: Incertezas e indefinições. Anais do XVII Congresso Nacional do CONPEDI, Brasília/DF, 20, 21 e 22 de novembro de 2008.

PORTAL BRASIL. Entenda como funciona o mercado de crédito de carbono. Disponível em: http://www.brasil.gov.br/meio-ambiente/2012/04/entendacomo-funciona-o-mercado-de-credito-de-carbono. Acesso em 29 mar. 2016.

SISTER, Gabriel. Mercado de Carbono e Protocolo de Quioto: Aspectos Negociais e Tributação. São Paulo: Campus Jurídico, 2008, p. 115.

STAFFEN, Márcio Ricardo; ZAMBAM, Neuro José. Direito global e desigualdades: um estudo a partir do "direito dos povos" de John Rawls. Revista Eletrônica do Curso de Direito da UFSM, v. 10, n. 1, p. 243-258, 2015.

VIOLA, Eduardo. O regime internacional de mudança climática e o Brasil. Revista Brasileira de Ciências Sociais. [online].v.17, n.50, 2002, p. 25-46.

YAZBEK, Otavio. Voto do Diretor no processo administrativo CVM no RJ 2009/6346. Disponível em: <http://www.cvm.gov.br/export/sites/cvm/decisoes/anexos/0005/6565-0.pdf>. Acesso em: 19 abr. 2016.

Submetido em: setembro/2016

Aprovado em: novembro/2016 